\title{
The Best Textbook of the National Flag for Patriotism Education in the New Era
}

\author{
Qin Shi ${ }^{1, *}$, Wendong Wang ${ }^{2}$ and Yikai Shi ${ }^{2}$ \\ ${ }^{1}$ Xi'an Medical University (Xi'an 710021,China) \\ ${ }^{2}$ Northwestern Polytechnical University (Xi'an 710072, China) \\ *Corresponding author. Email: shiqin@xiyi.edu.cn
}

\begin{abstract}
Patriotism is the spiritual core of the Chinese nation, and patriotism education in the new era is based on the themes of socialism with Chinese characteristics and the Chinese dream. The national flag is the symbol and sign of the country, representing our country's dignity and national spirit, culture, and beliefs. Using the national flag as the teaching material of patriotism is the most vivid, basic and concrete content and way to guide the people to cultivate patriotism. In this paper mainly introduces the new connotation of patriotism education in the new era. The national flag is the best teaching material for patriotism education. It discusses several enlightenments from using the national flag to develop patriotism education.
\end{abstract}

Keywords: The new era, Patriotism education, The national flag, Teaching material.

\section{INTRODUCTION}

The report of the 19th National Congress of the Communist Party of China in 2017 pointed out that socialism with Chinese characteristics has entered a new era. Under the leadership of the CPC Central Committee with Comrade Xi Jinping as the core, the whole party, the whole army and the people of all ethnic groups in China held high the national flag, faced difficulties, overcame difficulties and forge ahead, and successfully completed the first century goal of building a well-off society in an all-round way with constant determination, calm wisdom and courage to actively seek change. In 2021, China will advance towards the goal of building a prosperous, democratic, civilized and harmonious socialist modern country in the second century. Facing the new situation, challenges and tasks in the new socialist era, it is of great and far-reaching significance to carry forward the spirit of patriotism and realize the Chinese dream of the great rejuvenation of the Chinese nation. There are many contents and methods of patriotism education in the new era. Carrying out patriotism education with the national flag is the best teaching material to stimulate national patriotic feelings and unite powerful spiritual strength.

\section{THE CONNOTATION OF PATRIOTIC EDUCATION IN THE NEW ERA}

\subsection{Patriotism}

Patriotism is the true sense of responsibility and mission of every citizen of the Chinese nation to the country, and it is also the deepest and purest emotion to the country and the people. The Outline for the Implementation of Patriotism Education in the New Era clearly points out: "Patriotism is the national heart and soul of the Chinese nation, the most important spiritual wealth of the Chinese nation, and a powerful spiritual driving force for the Chinese people and the Chinese nation to safeguard national independence and national dignity." [1] Patriotism is the spiritual gene and "soul of China" precipitated by the Chinese nation over thousands of years. It is also the most natural, simple emotion and deep value of the Chinese nation. The Chinese nation has experienced a new era of socialism with Chinese characteristics from ancient times, modern times, modern times. Although the connotation of patriotism is different in different historical periods, as the national spiritual gene and lifeline, patriotism will always be engraved in people's thoughts and internalized in people's actions. 
General Secretary Xi Jinping pointed out: "The fate of the motherland is inseparable from the fate of Party and socialism. Only by adhering to the unity of patriotism, loving Party and socialism can patriotism be vivid and true, which is the most important embodiment of patriotism in contemporary China. In contemporary China, the essence of patriotism is to adhere to the high unity of patriotism, loving the Party and socialism. " [2] Patriotism must love socialism, love socialism must love the country, the unity of the two is the historical mission shouldered by the Communist Party of China. The Communist Party of China is a firm promoter and practitioner of patriotism. Since it was found 100 years ago, our Party has always taken national independence and rejuvenation, national prosperity and people's happy life as its goal. The Party led the Chinese people to fight bravely, overthrew the "three mountains", established the People's Republic of China, won the victory of the new-democratic revolution, and chose the socialist development path and system. Since the Third Plenary Session of the Eleventh Central Committee of the Communist Party of China, the Communist Party of China has always adhered to the people as the center, doing everything for the people and relying on the people, and taking seeking happiness for the Chinese people and rejuvenation for the Chinese nation as its initial intention and mission. Adhere to the combination of the basic principles of Marxism with the reality of the Chinese revolution, adhere to reform and opening up, and explore the socialist road, the system and theoretical system with Chinese characteristics. Our party has led the people of the whole country to create the rare "two miracles" of rapid economic development and long-term social stability. Do not forget your initiative mind and the brave mission of Communist Party of China are the firm leaders to realize socialist prosperity and development, national prosperity and national rejuvenation. Patriotism in the new era requires unifying love for the Party and patriotism into the cause of socialism with Chinese characteristics. The people of the whole country should closely unite around the CPC Central Committee with Comrade Xi Jinping as the core, forge ahead, overcome difficulties, and gather stronger spiritual strength for realizing the Chinese dream of the great rejuvenation of the Chinese nation. This is the truest and most vivid patriotism.

\subsection{Patriotism Education}

Patriotism is not born, but is formed through the edification and education of social environment. Patriotism education in the new era is a necessary way to realize the grand goals of the Party and the country, and is regarded as the "background color" of theme education. The Outline for the Implementation of Patriotism Education in the New Era clearly points out: "Strengthening patriotism education in the new era is of great and far-reaching significance for inspiring the national spirit, uniting the strength of the whole nation, winning the victory of building a well-off society in an all-round way, winning the great victory of socialism with Chinese characteristics in the new era, and realizing the Chinese dream of the great rejuvenation of the Chinese nation." [3] Patriotism education in the new era should be combined with distinct themes, essential requirements and development directions. Education should guide every citizen to form rational patriotic feelings with the characteristics of the times, and consciously practice the ambition of strengthening the country and the trip to serve the country.

Patriotism education has been endowed with different theoretical connotations in different periods. Accurately grasping the core connotation of patriotism education in the new era is helpful to deepen the comprehensive understanding of the theme, guiding the ideology and development direction of patriotism education in the new era, and to actively carry out patriotism education, thus carrying forward the spirit of patriotism.

First of all, the distinct theme of patriotism education in the new era is to realize the Chinese dream of the great rejuvenation of the Chinese nation. On November 18, 2012, General Secretary Xi Jinping put forward the "Chinese Dream" for the first time when leading comrades of the Standing Committee of the Political Bureau of the Central Committee to visit the exhibition on the road to rejuvenation, and explained many times that the "Chinese Dream" means "national prosperity, national rejuvenation and people's happiness". "Realizing the Chinese dream of the great rejuvenation of the Chinese nation is a distinct theme of contemporary Chinese patriotism." [4] The reason why the "Chinese Dream" is taken as the distinct theme of patriotism in the new era. This is because the "Chinese Dream" is related to China's development direction, embodies the long-cherished wish and expectation of several generations of Chinese people for the great rejuvenation of the Chinese nation, and bears the goal of the Communist Party of China to realize the great rejuvenation of the Chinese nation. The "Chinese Dream" is the dream and expectation of the Chinese people for a better life, which closely links the interests of the country, the nation and individuals. In the final analysis, it is the people's dream. Every Chinese is a participant and creator of the Chinese dream and must rely on the people to realize it.

Secondly, the essential requirement of patriotism education in the new era is to adhere to the unity of patriotism, loving Party and socialism. General Secretary Xi Jinping pointed out: "Patriotism is vivid and true only by adhering to the unity of patriotism, loving the Party and socialism. This is the most important embodiment of the patriotism spirit in contemporary China." [5] Since its establishment, the 
Communist Party of China has shouldered responsibility and mission of national rejuvenation, national prosperity and people's yearning for a better life, leading the Chinese nation to fight bloody battles to overthrow the "three mountains" on its head and save the people from the mire. It has won a great victory in the new democratic revolution and laid a solid foundation for building a new China. Having found a socialist suitable for national conditions and development, the Chinese nation has mastered its own destiny and made unremitting efforts to build a great country. The road, theory and system of socialism with Chinese characteristics have been created. Since reform and opening up, the CPC Central Committee with Comrade $\mathrm{Xi}$ Jinping as the core and the people of the whole country are undergoing unprecedented changes in a hundred years to adapt to the world, constantly exploring hard and paying a huge price, and exploring the only way to realize the Chinese dream of great rejuvenation of the Chinese nation. The historical practice of China's revolution, construction and reform shows that only the Communist Party of China can make a great leap for the Chinese nation from "standing up", "becoming rich" to "becoming strong".

Finally, the value trend of patriotism education in the new era is based on China and facing the world. Patriotism in the new era is not narrow, but based on China and facing the world. Today's era is a community era in which economic globalization and the destiny of all countries in the world share weal and woe. National prosperity and national rejuvenation are closely related to opening up to the outside world. Therefore, to carry forward the spirit of patriotism and combine it with the mind of an open and inclusive big country, we should not only be upright and innovative, strengthen the "four self-confidences", but also adhere to the concepts of "the belt and road initiative", "community of human destiny" and peaceful development, cooperation and win-win. This concept fully reveals the international responsibility and world mission of patriotism in the new era, and promotes the innovative development of patriotism. Although the novel coronavirus pneumonia outbreak in the world in 2020 also caused great losses to the Chinese economy However, the Chinese government and people still send expert groups to many countries around the world to provide anti-epidemic materials, vaccines. In the new era, it embodies the cosmopolitanism of patriotism in the new era, proves the openness and inclusiveness of patriotism in the new era, practices patriotism education and the world feelings of a big country, enhances the world's recognition of China, and jointly promotes the people of the world to create a better home.

\section{BEST TEXTBOOK FOR PATRIOTISM EDUCATION IN THE NEW ERA}

The purpose of patriotism education in the new era is to abstract patriotism theory into concrete and turn thought into action. It is to transform every citizen's patriotism and ambition to strengthen the country into concrete actions, to devote himself to the Chinese dream of the great rejuvenation of the Chinese nation, and to fulfill the mission and responsibility entrusted by the times. At present, China is in a critical period of realizing the great rejuvenation of the Chinese nation. Strengthening patriotism education is of practical significance for strengthening the national concept, enhancing the "four self-confidences" of the nation, and realizing the Chinese dream of the great rejuvenation of the nation to gather stronger spiritual strength. General Secretary Xi Jinping pointed out: "To carry forward the spirit of patriotism, patriotism education must be the eternal theme." "Carry out in-depth, lasting and vivid patriotic publicity and education among the majority of young people, let the patriotism spirit firmly take root in the hearts of the majority of young people, let the majority of young people cultivate patriotism, strengthen the country, practice the trip to serve the country, and let the patriotism spirit be passed down from generation to generation. Carry forward." [6].

How to carry out patriotic education in the new era has been discussed a lot. The five-star red flag is the symbol and symbol of the country, represents the authority and dignity of the country, has rich spiritual connotations, and embodies the lofty respect and deep feelings of the Chinese sons and daughters for the Party, the country and the nation. This paper holds that patriotism education in the new era by the national flag is the best teaching material, and it is also the best way for people to express patriotic feelings, enhance national consciousness, carry forward patriotic spirit, and cultivate and practice socialist core values.

No matter from the Olympic competition arena to the summit of Mount Everest, from the outer space of the vast universe to the deep sea exploration of 10,000 meters, from the Shenzhou high-speed rail that travels thousands of miles a day to the domestic large aircraft that flies in the clouds from fighting SARS in 2003 to fighting Novel Coronavirus in 2020 and so on. When the five-star red flag rises, every Chinese can't hide her passion and suppress her gushing tears. A feeling of incomparable pride and incomparable sacred-ness has emerged in this heart, because the five-star red flag is a national flag dyed by generations of benevolent people, a symbol of our great country, and a flag that will always inspire the Chinese people to overcome difficulties, work hard and forge ahead. Especially in 2020 , in the face of the sudden and serious global epidemic, the Party and the state insist on people's 
supremacy and life's supremacy, and put people's life safety and health first. Under the strong leadership of the Party, the Chinese people mobilized the whole society's forces and resources with firm courage and indomitable determination, and the whole country made concerted efforts, fearless of hardships and dangers, and made bold attacks, thus achieving decisive and significant strategic achievements in fighting the epidemic in a relatively short period of time. In this people's war against the epidemic, the national flag inspires medical staff, patients and the people of the whole country to forge ahead and overcome difficulties together. Whenever the national flag rises at the antiepidemic scene, the people of the whole country will strengthen their determination and confidence to overcome the epidemic, and they will deeply realize that "the country is behind us and doing its best to support us." This is the powerful spiritual strength brought to us by the five-star red flag[7]. Under the strong leadership of the CPC Central Committee, China has effectively controlled the epidemic situation, won a decisive victory in the fight against the epidemic, and steadily restored the production and living order, making China the only major economy in the world to achieve positive economic growth in 2020. General Secretary Xi Jinping pointed out: "The great anti-epidemic struggle has made us more convinced that with the strong leadership of the Communist Party of China, the great advantages of the socialist system with Chinese characteristics, and the majestic power of hundreds of millions of Chinese people to work together, China in the future will surely ride the wind and waves in the new voyage of national rejuvenation and go forward!" [8].

Since the 18th National Congress of the Communist Party of China, the CPC Central Committee with Comrade $\mathrm{Xi}$ Jinping as the core has placed poverty alleviation in a prominent position in governing the country, regarded poverty alleviation as the bottom line task of building a well-off society in an all-round way, adhered to the precise poverty alleviation strategy, and organized a massive people's war against poverty. General Secretary Xi Jinping's important speech at the National Summary and Commendation Conference on Poverty Alleviation solemnly declared that China had won a comprehensive victory in the fight against poverty. "The comprehensive victory in the fight against poverty marks a solid step taken by our party on the road of uniting and leading the people to create a better life and achieve common prosperity." [9] "The spirit of getting rid of poverty is a vivid portrayal of the nature and purpose of the Communist Party of China, and the spirit of the Chinese nation. It is a concentrated expression of patriotism, collectivism, and socialism. It is the full manifestation of Chinese spirit, Chinese values, and Chinese strength. It continues to inherit the great national spirit and the spirit of the times." [10] At the important moment of the centenary of the founding of the Communist Party of China, China has made great historic achievements in fighting poverty, It has created another miracle in the annals of history, which strongly demonstrates the political advantages of the leadership of the Communist Party of China and China's socialist system, and fully embodies the nature and purpose of our party's adherence to the people as the center, serving the people wholeheartedly and the essential requirement of socialism to achieve common prosperity.

\section{ENLIGHTENMENT OF PATRIOTISM EDUCATION WITH NATIONAL FLAG}

On January 1st, 2021, the newly revised National Flag Law of the People's Republic of China (hereinafter referred to as the New National Flag Law) came into effect. The new National Flag Law strengthens the standardization and seriousness of the use of the national flag, and improves the time and occasions for raising the national flag. The national flag is the symbol of the country, represents the authority and dignity of the country, and is the main content of the national system. The national flag is the best teaching material to show the weather of a big country, strengthen the national concept and carry out patriotic education. This article would like to talk about some suggestions on patriotism education with the national flag.

\subsection{Popularize the Knowledge of National Flag and Learn the New National Flag Law Well}

The national flag is the symbol of the country, represents the dignity of the country, and embodies the national spirit and patriotism. To carry out patriotic education with the national flag, we must first publicize and popularize the knowledge of the national flag and tell the story of the national flag. The main content includes the historical and spiritual connotation of the national flag. Many people may not be able to understand these contents clearly. By studying the knowledge of national flag, we can understand more stories behind the national flag, and people can understand that the national flag reflects the unity and stability, independence and progress, unity and dignity of the country. In order to save the survival of the nation, realize the rejuvenation of the nation and the prosperity of the country, the Communist Party of China has led countless people with lofty ideals to shed their heads and blood, and made unremitting efforts one after another. The national flag is the flag dyed by the blood of generations of benevolent people. With the popularization of national flag knowledge, people cultivate loyalty to the country through subtle infection and edification. Secondly, we should learn the new national flag law well. The main contents include the revised provisions of the new National Flag Law, which follow the spirit of the Constitution and further improve the legal system of national symbols, which is based on 
the Constitution. Learning and understanding the law is the premise of respecting and abiding by the law. By learning the new national flag law, the historical and spiritual connotation behind the national flag will be delivered to us. Through the in-depth study of new National Flag Law, people know that caring for the National Flag Law is not only patriotic, but also loving their families and themselves, establishing the consciousness of respecting and caring for the national flag, integrating the emotion of the national flag into the blood, and making the national flag a kind of belief and instinctive consciousness. In order to express the national sense of belonging and patriotism through the national flag, give full play to the important role of the national flag in patriotism education, and facilitate the popularization of national flag knowledge and learn the new national flag law well, the author suggests compiling the history of the national flag, the national flag pattern and its meaning, and the new national flag law into a book as a must-read textbook for every national.

\subsection{Expand the Use of the National Flag and Stimulate Patriotic Feelings}

The national flag is a monument and national soul in the heart of the Chinese nation. Whenever the five-star red flag rises countless times on Mount Everest, in outer space, in the Olympic Games, in the territory of the People's Republic of China, and all over the world, we can't hide our passion and tears, and patriotism arises spontaneously. Therefore, the national flag is the main form of patriotic education and an important part of cultivating people's national self-esteem and historical responsibility. Article 7 of the new National Flag Law stipulates: "State organs at all levels and people's organizations shall fly the national flag on National Day, International Labor Day, New Year's Day and Spring Festival. Enterprises and institutions, villagers' committees, residents' committees, urban residents' homes (buildings), squares, parks and other public venues can fly the national flag if conditions permit." To carry out patriotic education with the national flag, the utilization rate of the national flag should be expanded. The author suggests that the national flag should be hoisted not only on major festivals, but also in daily life. For example, a street, large supermarkets, schools, enterprises and institutions, large buildings, airports and other public places can see the national flag every day; Large LED electronic display screens of major units, shopping malls, airports, downtown areas, tourist attractions, etc. shall have standard national flag pattern pages; All kinds of major celebrations, commemorative activities, large-scale cultural and sport activities and large-scale exhibitions shall be hoisted with the national flag. In order to adapt to the use of national flags by citizens and organizations in appropriate occasions and express patriotic feelings, several national flags of proportional size with general scales can be specially produced to meet the needs of citizens in special circumstances and appropriate occasions (family cars, clothes, and tourism products, etc.). Let the national flag fly high over our great motherland, make the national flag and national concept deeply imprinted in everyone's heart, and make every Chinese national feel proud and proud of the national image, so that the whole world can know more about China and its image.

\subsection{Strengthen the Role of Supervision and Put it in Place}

Article 4 of the newly revised National Flag Law stipulates: "Local people's governments at all levels shall supervise and manage the raising and use of national flags within their respective administrative areas." To further strengthen the supervision and management of the use of national flags, Clarify the regulatory responsibilities for the production, sale, lifting, use and recycling of the national flag. The draft adds provisions: "The departments determined by the State Council coordinate the work related to the management of the national flag nationwide, and the market supervision and management departments of local people's governments at all levels supervise and manage the production and sales of flags within their respective administrative areas; The departments determined by the people's governments at the county level shall supervise and manage the raising, use and recycling of the national flag within their respective administrative areas. ". The new national flag law makes the use of national flag and national emblem normative and serious, and further improves the legal system of national symbols, which is the proper meaning of building a society ruled by law and helps to enhance the legal awareness of relevant departments and nationals. More importantly, there are more laws to follow for the development of supervision work, which is conducive to further strengthening the national flag supervision responsibilities of people's governments at all levels and supervision departments, and ensuring that the National Flag Law and the National Emblem Law are put in place. The author suggests that people's governments at all levels should set up supervision departments for the production, sale, lifting, use and recycling of national flags. The person in charge of the department has clear responsibilities, and it is necessary to combine comprehensive supervision with decentralized law enforcement, especially to check the implementation of the use of the national flag, so as to achieve the goal of accurate and efficient supervision.

\section{CONCLUSION}

Patriotism education in the new era is an important project to consolidate the foundation and cultivate the belief. Only by persisting in unremitting efforts and 
through long-term subtle education and training, it can be internalized in the national consciousness and actions. As the symbol of the country, the national flag has become an important way for the Chinese nation to express its love for the Party, patriotism and socialism and enhance its national concept with the continuous development of the national flag and its patterns from government agencies to society and from holidays and celebrations to daily life. At present, China is striving for the goals of "the second century", "the belt and road initiative" and "community of human destiny", under the lead of $\mathrm{Xi}$ Jinping's thought of socialism with Chinese characteristics. The Chinese people will put the patriotic feelings stimulated by the national flag into the great practice of national construction, and give full play to our intelligence, enthusiasm and creativity to realize the Chinese dream of the great rejuvenation of the Chinese nation.

\section{ACKNOWLEDGMENTS}

Fund Sponsorship:Shaanxi Province's key research project on higher education teaching reform (17bG029).

\section{REFERENCES}

[1] Implementation Outline of Patriotism Education in the New Era. Beijing: China Legal Publishing House,2019.4.

[2] Xi Jinping. Vigorously carry forward the great patriotism spirit and provide spiritual support for realizing the Chinese dream. Beijing: Guangming Daily, 2015-12-31(01).
[3] CPC Central Committee and State Council: Implementation Outline of Patriotism Education in the New Era. Beijing. People's Daily, 2019-11-13(6).

[4] Literature Research Office of CPC Central Committee. Excerpts from Xi Jinping's Discussion on Building a Well-off Society in an All. Beijing.Central Literature Publishing House, 2016: 133.

[5] Xi Jinping. Vigorously carry forward the great patriotism spirit and provide spiritual support for realizing the Chinese dream. Beijing: Guangming Daily, 2015-12-31(01).

[6] Xi Jinping. Vigorously carry forward the great patriotism spirit and provide spiritual support for realizing the Chinese dream. Beijing: Guangming Daily, 2015-12-31(01).

[7] Peng DY.Newly Revised National Flag Law: Consolidate a Stronger Spiritual Force to Realize the Chinese Dream. Beijing: National People's Congress of China. 2020-10-20. 30-31.

[8] Xi Jinping. Speech at the National Commendation Conference on Combating novel coronavirus pneumonia Epidemic. Beijing: Qiushi, 2020-20.

[9] Xi Jinping. Speech at the National Summary and Commendation Conference on Poverty Alleviation. Beijing: People's Publishing House, 2021.

[10] Xi Jinping. Speech at the National Summary and Commendation Conference on Poverty Alleviation. Beijing: People's Publishing House, 2021. 